Original article

\title{
Yüzdeler Öğretiminde Matematiksel Modelleme Etkinlikleri Kullanımına İlişkin Öğrenci Görüşleri
}

Student's Opinions on the Use of Mathematical Modeling Activities in Teaching Percentages

\author{
Aydan Kurtuluş Kayan \\ Hamidiye Secondary School, Rize, Turkey
}

\begin{abstract}
Özet
Günümüzde eğitimdeki hızlı gelişmeler sayesinde günlük hayatla ilişkilendirilen matematiksel modelleme, matematiksel beceriler arasında yerini almıştır. Literatürde yer alan matematiksel modelleme etkinlikleriyle ilgili ülkemizde yapılan çalışmalar incelendiğinde ilkokul ve ortaokul düzeyinde uygulamaya yönelik çalışma açısından eksiklikler olduğu ifade edilebilir. Bu noktadan hareketle bu araştırmada günlük hayatta en çok karşılaştığımız ancak öğrencilerin derslerde en çok zorlandıkları konulardan biri olan yüzdeler ile ilgili modelleme etkinliklerine yönelik çalışma yapılmasının gerekli olduğu düşünülmüştür. Bu bağlamda çalışmanın amacı yüzdeler öğretiminde matematiksel modelleme etkinlikleri kullanımına ilişkin öğrenci görüşlerini incelemek şeklinde belirlenmiştir. Bu kapsamda nitel yaklaşımla oluşturulmuş çalışmada durum çalışması yöntemi kullanılmıştır. Araştırmanın çalışma grubunun 2017-2018 Eğitim Öğretim yılında Rize'de bir devlet okulunun 7. sınıfında öğrenim gören 21 öğrenci oluşturmaktadır. Ortaokul 7. sınıf düzeyinde bir ünitenin kazanımlarına paralel bir şekilde hazırlanan matematiksel modelleme etkinlikleri destekli yürütülen dersler sonrasında araştırmacı tarafından geliştirilen matematiksel modelleme etkinlikleri öğrencilere uygulanmıştır. Çalışmanın verileri bu etkinliklerin sonunda yapılan yarı yapılandırılmış görüşmeler aracılığıyla elde edilmiştir. Verilerin analizinde içerik analizi yöntemi kullanılmıştır. Sonuçlar, matematiksel modelleme etkinlikleriyle yapılan öğretimin öğrencilere kazandırdıklarının başında matematik ve günlük hayat arasındaki ilişkiyi anlamlandırma, eğlenceli ders ortamı, etkin katıım geldiğini ortaya koymaktadır. Ayrıca görüşmelerden elde edilen sonuçlara göre öğrencilerin uygulama öncesinde matematiğin günlük hayattaki yerinin farkında oldukları ancak matematiksel modelleme etkinlikleriyle çalıştıktan sonra bu ilişkinin daha geniş bir alana yayıldığını fark ettikleri tespit edilmiştir.
\end{abstract}

Anahtar Kelimeler: Modelleme, matematiksel modelleme etkinlikleri, yüzdeler öğretimi, öğrenci görüşleri.

\begin{abstract}
Today, mathematical modelling which is associated with daily life thanks to the rapid changes in education has taken its place among mathematical skills. When the studies counducted in our contury on mathematical modelling activities are reviewed, it can be stated that there are deficiencies in terms of practical study in primary and secondary school levels. From this point of view, in this study it was thought that it is necessary to conduct a study on modelling activities about percentages which is one of the topics that we run into most in daily life but the most difficulty in lessons. At this point, the aim of the study was determined as examining learner opinions on the use of mathematical modeling activities in teaching percentages. In this scope, case study method was used in the study created with qualitative approach. 21 7th-grade students who were studying at a public school in
\end{abstract}

\footnotetext{
* Corresponding author:

Aydan Kurtuluş Kayan, Hamidiye Secondary School, Rize, Turkey Email: aydankurtulus@hotmail.com
} 
Rize in the 2017-2018 academic year compose the study group of the research. The mathematical modelling activities that were developed by the researcher were applied to the students after the lessons which were conducted with the support of mathematical modeling activities prepared in parallel with the acquisitions of a unit at the 7th grade level of secondary school. The data of the study were obtained through semi-structured interviews at the end of these activities. Content analysis method was used in the analysis of data. The results reveal that making sense of the relationship between mathematics and daily life, a fun course environment, and active participation are at the top of what the teaching conducted with mathematical modeling activities has brought to students. Moreover, in these interviews the students indicated that they were also aware of the mathematics' place in daily life before the applications but this relationship expanded to a broader area after studying with mathematical modeling activities.

Keywords: Modeling, mathematical modeling activities, percentages teaching, learner opinions.

Received: 16 September $2020 \quad$ * Accepted: 30 December $2020 \quad * \quad$ DOI: https://doi.org/10.29329/jpee.2020.282.4

\section{GİRIŞ}

Günümüzde bilimdeki hızlı gelişme hayatımızın her alanını etkilemektedir. Bu alanların başında da eğitim gelmektedir. Bilim ve eğitimdeki gelişmelerin paralel olarak ilerlemesi ve bu gelişmelere ayak uydurmamız önem arz etmektedir. Bilimdeki ve beraberinde teknolojideki gelişim kendi hızında, farklı kaynakları kullanabilen ve problem çözme becerileri çok gelişmiş yani farklı becerilere sahip bireyler yetiştirmeyi mümkün kılmaktadır (Doruk, 2010; Erol, 2015; Kal, 2013). Sürekli değişen ve gelişen bilim alanlarından biri de matematiktir (Kilpatrick, 1992). Matematik dilini etkin kullanabilen, gerçek hayat problemlerine etkili çözümler üretebilen, bu çözümleri günlük hayatında kullanabilen ve bunu beceri haline getirebilen bireyler yetiştirmek matematiğin asıl hedeflerinden biridir (Blum ve Leib, 2007; Bukova-Güzel, 2016; Doruk, 2010). Yapılan araştırmalar, okul ortamında öğrenilen matematiksel bilginin günlük hayatla ilişkilendirilememesinden dolayı özellikle ülkemizdeki öğrencilerin düşük akademik başarı gösterdiğini ve matematiğe karşı olumsuz tutum sergilediğini ortaya koymuştur (Mumcu ve Baki, 2017). Bu noktada öğretim sürecinde, günlük hayatla ilişkilendirilen matematiksel modelleme etkinlikleri kullanımın çok önemli bir yeri vardır (Akgün vd., 2013; Doruk, 2010; Erbaş, Kertil, Çetinkaya ve Çakıroğlu, 2014; Keskin, 2008).

Matematiksel model ve matematiksel modelleme kavramlarına gelmeden önce model ve modellemenin ne ifade ettiği anlaşılmalıdır. Gilbert'e (2000) göre en genel anlamıyla model bir fikir, bir obje veya bir olgunun görselleştirilmesi olarak tanımlanmaktadır (Akt: Gümüş vd., 2008). Modelleme ise Lesh ve Doerr'e (2003) göre, günlük hayat problemlerine açıklık getirebilme amacıyla model oluşturma sürecidir. Bu süreçte modeller bazen araç ve bazen de ürün olarak karşımıza çıkmaktadır (Hıdıroğlu, 2012). Modelleme, modelin oluşmasına hizmet eden birbiriyle ilişkili aşamaları 
olan döngüsel bir süreçtir. Yani modelleme sürecinde izlenen aşamalar gerektiğinde yerlerinin değişebildiği ve gerektiğinde geriye dönülebildiği bir yapıdadır (Çiltaş, 2011).

En genel tanımla gerçek hayat problemlerinin matematiksel olarak anlamlandırılması, çözüme ulaştırılması ya da bir matematiksel forma dönüş̧ürülmesi, bu matematiksel formun tekrar gerçek hayata döndürülmesini içeren karmaşık sürece matematiksel modelleme denir (Berry ve Houston, 1995). Kertil'e (2008) göre matematiksel modelleme, karşı karşıya gelinen problem durumlarının matematiksel olarak yorumlanabilmesi için gereken kavramsal yapılardır. Kapur'a (1998) göre matematiksel modelleme süreci gerçek hayat problemlerini tercüme eden aynı zamanda matematiksel problemleri de gerçek yaşam problemlerine uyarlayan süreçtir. Swetz ve Hartler'e (1991) göre ise matematiksel modelleme başlı başına bir problem çözme türüdür. Okul ortamlarında öğrencilere sunulan problemlerde, çözüm için genel bir form vardır ve birkaç işlemle bir doğru cevap elde edilmesi istenir. Oysaki problem günlük hayatta var olmalıdır. İşte bu noktada matematiksel modelleme sistematik bir süreç olup yorumlama, analiz ve sentez gibi üst düzey bilişsel becerilerin gelişimine katkı sağlar (Sandalc1, 2013). Matematiksel modelleme, öğrencilerin problemlerin doğasındaki ilişkilerini görebilmesini, matematik terimleriyle ifade edebilmesini, sınıflandırabilmesini, genelleyebilmesini ve sonuç çıkarabilmesini kolaylaştıran dinamik bir süreçtir (Milli Eğitim Bakanlığı (MEB), 2013). Bu süreçte gerçek yaşamla matematik ilişkilendirilir. Matematiksel modellemenin gerçek hayatla matematik arasında bir köprü kurulmasını sağlaması ve pratik çözüm yollarını üretebilme olanağını sunması son yıllarda birçok matematik eğitimi araştırmacılarının eğitimde matematiksel modelleme üzerinde çalışmalar yapmalarına neden olmaktadır (Kertil, 2008).

Literatür incelendiğinde, Beyazıt, Aksoy ve Kırnap (2011) öğretmenlerle matematiksel modelleri anlama ve model oluşturma yeterlilikleri ile ilgili yaptıkları çalışmada modellemenin sağlayacağı katkılar konusunda öğretmenlerin olumlu inançları olmasına rağmen model algılarının şekil ve şemalarla kısıtlanmış olduğunu belirlemişlerdir. Başka bir çalışmada Çelik ve Çiltaş (2015), matematik öğretmenlerinin kesirler konusunun öğretim süreçlerinde matematiksel modelleri kullanım düzeylerini belirleyerek öğretmenlerin konuyu görselleştirdiği ve kalıcılığı artırdığı için modelleri faydalı bulduğu sonucuna ulaşmışlardır. Diğer bir araştırmada ise Hıdıroğlu ve Özkan-Hıdıroğlu (2017), daha önce hiç modelleme etkinliğiyle karşılaşmayan altıncı sınıf öğrencileriyle yürütmüş olduğu çalışmada öğrencilerin bu süreçte zorlandıklarını, çözüm için gereksiz çizimlere yer verdiklerini ve hatalı tahminlerde bulundukları için gerçekçi bir model elde edemediklerini belirlemiştir. Bu durum da onların ilerleyen basamaklarda beklenen seviyede başarı gösterememelerine neden olmuştur. Karabörk (2016) 7. Sınıf öğrencileriyle model oluşturma etkinlikleri hakkındaki görüşleri üzerine yaptığı çalışma neticesinde öğrenciler; etkinliklerin zor, uğraştırıcı ama eğlenceli olduğunu ifade etmişlerdir. Ayrıca akademik başarı anlamında da anlamlı bir farklılık tespit edilmiştir. Muşlu ve Çiltaş (2016) matematiksel modelleme yöntemi kullanılarak işlenen ders ile ilgili 5. sınıf öğrencilerinin başarılarına 
etkisini incelemek amaçlı yaptıkları çalışmanın sonucunda deney grubu lehine akademik başarı anlamında anlamlı bir farklılık görülmüştür. Ayrıca öğrencilerin matematiğe karşı olumlu tutum kazandıkları, kavramları daha iyi anlamlandırdıkları ve modelleme etkinliklerinde karşılaştıkları günlük hayat problemlerinin çözüm sürecini öğrenmiş oldukları tespit edilmiştir. Yapılan araştırmaları incelediğimizde ülkemizde yapılan matematiksel modelleme araştırmalarında modelleme etkinlikleri ile yapılan öğretimin bir araç olarak kullanıldığı görülmektedir. Ülkemizde yayınlanan matematiksel model ve modelleme ile ilgili çalışmaların, öğrencilerin matematiğe karşı tutum, ilgi, kaygı ve yeterliklerini ölçmeye çalışan çalışmalar olduğu görülmektedir. Ayrıca matematiksel modellemeye yönelik araştırmaların benimsedikleri modelleme türünde karma matematiksel modellemenin öne çıktığı, belirli konu ve kavramlar yerine, farklı matematiksel konular üzerinden öğrenme ortamının oluşturulduğu görülmüştür. Bu çalışmada tek bir konu üzerine yoğunlaşılmasının anlamlı öğrenme için daha faydalı olacağı düşülmüştür.

Günlük hayatta sık sık karşılaştığımız ve kullandığımız konulardan biri de yüzdelerdir. Yüzde kavramının çeşitli anlamları birçok araştırmacı tarafından ele alınmıştır. En genel tanımıyla yüzde, paydası 100 olan standart oran için kullanılan diğer bir isimdir. İşlem olarak kullanıldığında bir bütünün 4/ 3’ü aynı bütünün 0,75'i veya \%75'i ile aynıdır. Böylece yüzde kavramı yeni bir kavram olarak değil, sadece yeni bir gösterim ve terminoloji olarak düşünülebilir (Van de Walle, Karp ve Bay-Williams, 2012). Yüzdeler konusunun matematikte ve günlük hayatta çok önemli bir yeri olmasına rağmen birçok araştırma sonucu öğrencilerin hatta yetişkinlerin bile yüzde konusunda zorlandıklarını ortaya koymaktadır (Koay, 1998; Lembke ve Reys, 1994; Parker ve Leinhardt, 1995; Van de Walle vd., 2012). Bu düşük başarının sebebini Van de Walle ve arkadaşları (2012) yüzde kavramının anlamlı bir şekilde geliştirilememesine bağlamaktadır. Koay’a (1998) göre, yüzdeler konusunda yapılan geleneksel eğitim öğrencilerin yüzde problemlerine yaklaşımlarındaki yaratıcılıklarını ve esnekliklerini engellemektedir. Ortaokul seviyesindeki öğrenciler için yüzdeler konusu matematiği günlük hayatla ilişkilendirme açısından oldukça önemlidir. Modelleme etkinlikleri gerçek yaşam durumlarını sınıf ortamına taşımada etkili bir araç olduğu için ortaokul düzeyindeki yüzdeler konusunun öğretimine yönelik modelleme etkinliği kullanımının araştırılması gerekli bir konu olarak görülmektedir

Matematiksel modelleme etkinlikleri bir problemin öğrenciler tarafından anlaşılıp, tanımlanmasına ve çözülmesine imkân sağlayarak matematiksel dilin keşfinde öğrencilere rehberlik edebilecek süreçleri içerir (Albayrak, 2017). MEB (2015) öğretim programında da yer alan amaçlardan biri öğrencilerde matematiksel dilin gelişimidir. Çalışma için geliştirilen matematiksel modelleme etkinliklerinin bu yönüyle öğretim programının amaçlarıyla uyum içerisinde olacağı söylenebilir. Ayrıca matematiksel modelleme etkinlikleriyle ilgili çalışmalar incelendiğinde, çalışma grubu olarak daha çok lisans öğrencileri ile çalışmalar yapıldığ görülmektedir (Albayrak, 2017; Çiltaş, 2017; Doruk, 2010). Oysaki matematiksel modelleme çalışmalarının temelini daha erken yıllarda atılması gerektiği 
düşünülmektedir. Eğitimde yeni yaklaşımlara uygun olarak hazırlanan matematik programında modellemenin önemi vurgulanmakta ancak modelleme etkinliklerinin nicelik boyutunda eksiklikler olduğu görülmektedir. Araştırmada ortaokul düzeyinde matematiksel modelleme etkinliklerinin uygulanması ve bu uygulamaların getirilerinin tartışılması ilerleyen yıllarda programdaki bu eksikliğin giderilmesine de katkı sağlayacağı düşünülmektedir. Bu sebeplerden dolayı, bu durum araştırmasının amac1, yüzdeler öğretiminde matematiksel modelleme etkinlikleri kullanımına ilişkin öğrenci görüşlerini ortaya koymak olarak belirlenmiştir. $\mathrm{Bu}$ amaç doğrultusunda araştırmanın problemi "Yüzdeler öğretiminde matematiksel modelleme etkinlikleri kullanımına ilişkin öğrenci görüşleri nelerdir?" şeklinde belirlenmiştir.

\section{YÖNTEM}

\section{Araştırmanın Modeli}

$\mathrm{Bu}$ araştırmada, yüzdeler öğretiminde matematiksel modelleme etkinlikleri kullanımına ilişkin öğrenci görüşlerini ortaya koymak amaçlandığından nitel yaklaşıma dayalı olan durum çalışması yöntemi kullanılmıştır. Nitel araştırmanın en önemli özelliği, üzerinde araştırma yapılan kişilerin bakış açılarıyla araştırılan olay, olgu, norm ve değerleri incelemeye çalışmasıdır. Durum çalışması, bir olgu ya da olayı gerçek hayat çerçevesi içinde çalışan, bu çerçeve ile olgu arasındaki sınırların keskin hatlarla ayrılmadığı, birden çok kanıt ve veri aracının olduğu durumlarda kullanılan görgül araştırma yöntemine denir (Yıldırım ve Şimşek, 2016). Bu tanımlamalar çalışmanın amacı ile karşılaştırıldığında, durum araştırmasının çalışmanın doğasına uygunluğu açıktır.

\section{Çalışma Grubu}

Bu araştırma, 2017-2018 Eğitim Öğretim yılında Rize ilindeki bir ortaokulda 21 öğrenciye uygulanmıştır. Araştırmanın çalışma grubu belirlenirken amaçlı örnekleme yöntemi kullanılmıştır. Çünkü bu yöntemde zengin bilgiye sahip olduğu düşünülen durumların derinlemesine çalışılmasına olanak verilmektedir (Yıldırım ve Şimşek, 2016). Amaçlı örneklemede araştırmacı kimlerin seçileceği konusunda kendi yargısını kullanır ve araştırmanın amacına en uygun olanları örnekleme alır (Balcı, 2018).Bu çalışmada da yüzdeler konusunun 7.sınıf düzeyinde öğretiliyor olmasından dolayı 7. sınıfların çalışma grubu olarak belirlenmesine karar verilmiştir.

\section{Veri Toplama Araçları}

$\mathrm{Bu}$ araştırmada yüzdeler öğretiminde matematiksel modelleme etkinlikleri kullanımına ilişkin öğrencilerin görüşlerini elde etmek amacıyla yarı-yapılandırılmış görüşme tekniği kullanılmıştır. Araştırma sürecinden elde edilen verilerin kaynağını, matematiksel modelleme etkinlikleriyle yapılan öğretimin sonrasında uygulanan görüşme soruları oluşturmaktadır. Görüşme soruları iki matematik eğitimi uzmanı tarafından incelenmiş ve onay alınmıştır. Öğretim tamamlandıktan sonra en son yapılan ölçme sınavı sonuçlarına bakılırak düşük, orta ve yüksek başarı düzeyine sahip 4 öğrenci ile matematiğin 
hayatımızdaki yeri ve etkinliklerin öğrencilerin aşina oldukları problemlerden farklılıkları hakkındaki sorularla yarı yapılandırılmış görüşmeler yapılmıştır. 8 sorudan oluşan görüşme soruları hem günlük hayatla ilgili hem de öğrenme ortamıyla ilgili öğrenci görüşlerini belirleme amaçlı sorulardır. Yapılan görüşmeler kayıt altına alınmıştır. Kayıtlar araştırmacı tarafından çözümlenerek yazıya dökülmüştür.

\section{Verilerin Toplanması}

Uygulamaya başlanmadan önce matematik programındaki sayılar öğrenme alanının yüzdeler alt öğrenme alanı incelenmiştir. 7. Sınıf programındaki yüzdeler konusunun kazanımları odak noktası olarak seçilmiştir. Uygulama için 2 hafta süre ayrılmıştır. Her kazanım için en az bir tane modelleme etkinliği hazırlanmış ve uygulama süresince toplam 6 modelleme etkinliğine yer verilmiştir. Hazırlanan modelleme etkinliklerinin uygunluğu 2 matematik uzmanı tarafından incelenmiştir. Araştırma süreci Tablo 1'de gösterilmiştir.

Tablo 1. Araştırma Süreci

\begin{tabular}{lll}
\hline Grup & İşlem & Son Test \\
\hline 7.sınıf & 2 Haftalık Grupla Çalışma (Matematiksel Modelleme Etkinlikleriyle Öğretim) & Görüşme
\end{tabular}

Tablo 1'de araştırmanın süreci ile ilgili bilgilere yer verilmiştir. 7. Sınılara uygulanacak matematiksel modelleme etkinlikleri 2 hafta sürmüştür. Etinliklerle süren öğretimden sonra öğrencilerle yarı yapılandırılmış görüşmeler yapılmıştır.

Matematiksel modelleme etkinlikleri hazırlanırken etkinliklerin günlük hayatla ilişkili olmasına ve öğrencilerin yaşlarına uygunluğu göz önünde bulundurulmuştur. Uygulama sırasında öğrenciler 2'şer kişilik gruplara ayrılmışlardır. Araştırmacı kendi dersinde matematiksel modelleme etkinlikleriyle öğretim uygulamalarını gerçekleştirmiştir. Her gruba modelleme etkinlikleri dağıtılmış ve yeterli süre verilmiştir. Etkinlikte yer alan problem durumuna çözüm önerileri getirmeleri istenmiştir. Şekil 1'de uygulamalarda kullanılan matematiksel modelleme etkinliklerinden birine yer verilmiştir. 


\section{FUTBOL PROBLEMI}

Fenerbahçe-Galatasaray arasında oynanan derbi maçı için A kanalı maç sonrası analiz yapacaktır. İlk yarısı 45 dk. olan maçın ilk yarı topla oynama, toplam şut ve başarı pas sayıları aşağıdaki tabloda verilmiştir. Maç analizcileri ilk yarı bilgilerinin yüzdelerini bulmanızı ve bu verilerden yola çıkarak maçı kimin kazanabileceğini yüzdelerle ifade etmenizi istiyorlar. Bu verilerden bir rapor yazıp yardım etmelisin.

\begin{tabular}{|l|l|l|l|l|}
\hline IIlk Yarı Verileri & FENERBAHÇE & YÜZDE & GALATASARAY & YÜZDE \\
\hline $\begin{array}{l}\text { Topla Oynama } \\
\text { Süreleri }\end{array}$ & $20 \mathrm{dk}$. & & $25 \mathrm{dk}$. & \\
\hline Toplam Şut & 8 & & 2 & \\
\hline Başarılı Paslar & 120 & & 130 & \\
\hline
\end{tabular}

Şekil 1. Uygulamada kullanılan örnek matematiksel modelleme etkinliği

Şekil 1'de verilmiş olan modelleme etkinliği "Bir çokluğu belirli bir yüzde ile arttırmaya yönelik hesaplamalar yapar" kazanımına aittir. Öğrencilerin ders kitaplarında aşina oldukları soruların aksine öğrencilerin farklı düşünmelerini sağlayacak bir modelleme etkinliğidir.

\section{Verilerin Analizi}

Araştırma için gerekli nitel veriler matematiksel modelleme etkinlikleri öncesi ve sonrasında ögrencilerle yapılan yarı yapılandırılmış görüşmeler aracılığıyla elde edilmiştir. Yarı yapılandırılmış görüşme sorularının geliştirilme aşamasında inanırlığı sağlamak amacıyla matematik eğitiminde uzman görüşlerine başvurulmuştur. Öğrencilerle yapılan yarı yapılandırılmış görüşmelerden elde edilen nitel veriler içerik analiz yöntemi ile analiz edilmiştir. İçerik analizinde temel amaç, elde edilen verileri açıklayabilecek kavramlara ve ilişkilere ulaşmaktır. Bu sebeple önce veriler kavramsallaştırılır daha sonra ortaya çıkan kavramlar 1şında mantıklı bir şekilde düzenlenir ve veriyi açıklayan kategoriler saptanır (Yıldırım ve Şimşek, 2016). İçerik analizinde temelde yapılan işlem, birbirine benzeyen verileri belirli kavramalar ve kategoriler çerçevesinde bir araya getirmek ve bunları okuyucunun anlayabileceği bir biçimde düzenleyerek yorumlamaktır. $\mathrm{Bu}$ çerçevede görüşme sorularından elde edilen veriler okunup düzenlenmiştir ve temalar oluşturulmuştur.

Araştırmanın iç geçerliliğini sağlamak için literatür taraması yapılmış ve kavramsal bir çerçeve oluşturulmuştur. Araştırmanın dış geçerliliğini sağlamak amacıyla ise araştırmanın tüm aşamaları yorum katılmadan açıklanmaya çalışılmıştır. Araştırmanın iç güvenirliliği noktasında bulgular ham ve kodlanmış şeklinde verilmiştir. Dış güvenirlilik için ise araştırmanın başından sonuna kadar izlenen yolu ve alınan kararlar ayrıntılı şekilde ifade edilmiştir. Ayrıca katılımcılara ait bilgiler gizli tutulmuş ve Ayrıca öğrenciler Ö1, Ö2, ... şeklinde kodlanmıştır. 


\section{BULGULAR}

Matematiksel modelleme etkinlikleri kullanılarak yapılan öğretime ilişkin öğrenci görüşlerinin belirlenmesi sonucu elde edilen bulgular soru bazında değerlendirilerek elde edilmiştir. Katılımcıların düşünce ve görüşleri ile elde edilen kodlar Tablo 2'de yer almaktadır. 
Tablo 2. Matematiksel Modelleme Etkinlikleriyle Yapılan Öğretime İlişkin Öğrenci Görüşleri

\begin{tabular}{|c|c|c|c|c|c|c|c|}
\hline Öğrenciler & $\begin{array}{l}\text { Matematiğe Bakış } \\
\text { Açısı }\end{array}$ & Anlama & $\begin{array}{l}\text { Ĕglenerek } \\
\text { Öğrenme }\end{array}$ & Grup Çalışmaları & $\begin{array}{l}\text { Günlük Hayatla } \\
\text { İlişki }\end{array}$ & Etkin Katılım & $\begin{array}{l}\text { Matematiksel } \\
\text { Beceriler }\end{array}$ \\
\hline Ö1 & $\begin{array}{l}\text { "Bilmediğim } \\
\text { alanlarda } \\
\text { matematiğin } \\
\text { olduğunu fark } \\
\text { ettim" Sağlik ve } \\
\text { spor alanlarında } \\
\text { var." }\end{array}$ & $\begin{array}{l}\text { "Soyut olan } \\
\text { matematik bir anda } \\
\text { somutlaşmaya } \\
\text { başladı" }\end{array}$ & & $\begin{array}{l}\text { Ben futbol } \\
\text { etkinliğini pek } \\
\text { anlayamamıştım. } \\
\text { Bu yüzden grup } \\
\text { arkadaşımdan } \\
\text { yardım aldım. }\end{array}$ & $\begin{array}{l}\text { "Modelleme } \\
\text { etkinliklerinde daha } \\
\text { çok günlük hayatla } \\
\text { ilişkili şeyler vardı." }\end{array}$ & $\begin{array}{l}\text { "Herkes etkinliklere } \\
\text { katılıyor ve herkesin } \\
\text { dikkatini çekiyor" }\end{array}$ & $\begin{array}{l}\text { Modelleme } \\
\text { etkinliklerinde şık } \\
\text { yok ve yorum } \\
\text { katma var (Akıl } \\
\text { Yürütme). }\end{array}$ \\
\hline Ö2 & $\begin{array}{l}\text { "Çoğu alanda } \\
\text { matematik } \\
\text { olduğunu gördüm." }\end{array}$ & $\begin{array}{l}\text { "Etkinlikler } \\
\text { sayesinde yüzdeler } \\
\text { konusunu daha iyi } \\
\text { anladığımı } \\
\text { düşünüyorum." }\end{array}$ & $\begin{array}{l}\text { "Etkinlikleri } \\
\text { eğlenceli buldum" }\end{array}$ & & $\begin{array}{l}\text { "Neredeyse her } \\
\text { yerde var. } \\
\text { Bakkalda, inşaatta, } \\
\text { mühendislik } \\
\text { alanında, yemek } \\
\text { yaparken var." }\end{array}$ & $\begin{array}{l}\text { "Derste bazı kişiler } \\
\text { dersi dinlemiyordu } \\
\text { ama etkinlikler } \\
\text { sayesinde çoğu kişi } \\
\text { derse katıldı." }\end{array}$ & $\begin{array}{l}\text { “Testte doğru bir } \\
\text { şık var ama } \\
\text { etkinliklerde herkes } \\
\text { farklı farklı } \\
\text { cevaplar buluyor } \\
\text { (Akıl Yürütme). }\end{array}$ \\
\hline Ö3 & $\begin{array}{l}\text { "Kendi } \\
\text { vücudumuzda } \\
\text { olduğunu fark ettim. } \\
\text { İlk yaptığımız } \\
\text { market etkinliğine } \\
\text { göre hangi market } \\
\text { daha tasarruflu olur } \\
\text { onu öğrendim." }\end{array}$ & & $\begin{array}{l}\text { "Etkinlikler } \\
\text { eğlenceli ve güzeldi } \\
\text { bence" }\end{array}$ & $\begin{array}{l}\text { Grup çalışmasını } \\
\text { daha iyi kavramış } \\
\text { oldum. Arkadaşımla } \\
\text { iletişime geçmeye } \\
\text { başladım. } \\
\text { Eksiklerimizi } \\
\text { tamamlamadık. }\end{array}$ & $\begin{array}{l}\text { “Alışveriş yaparken, } \\
\text { bankaya fatura } \\
\text { ödemeye giderken, } \\
\text { mimarlar, } \\
\text { mühendisler ev } \\
\text { tasarlarken } \\
\text { matematiği } \\
\text { kullanırlar” }\end{array}$ & & $\begin{array}{l}\text { "Bu etkinliklerdeki } \\
\text { verileri genelde biz } \\
\text { oluşturduk ve öyle } \\
\text { yaptık. Tek bir } \\
\text { cevap yoktu farklı } \\
\text { yollar vardı. (Akıl } \\
\text { Yürütme) } \\
\text { Tahminlerimiz } \\
\text { vardı (Tahmin } \\
\text { Becerileri). }\end{array}$ \\
\hline Ö4 & $\begin{array}{l}\text { "Matematiği daha } \\
\text { çok sevmeye } \\
\text { başladım. } \\
\text { Matematiğe daha } \\
\text { çok önem vermem } \\
\text { gerektiğini gördüm } \\
\text { çünkü matematik } \\
\text { hayatın her alanında } \\
\text { varmış." }\end{array}$ & $\begin{array}{l}\text { "Eğitici yönü çok } \\
\text { fazla." }\end{array}$ & $\begin{array}{l}\text { "Modelleme } \\
\text { etkinlikleri çok } \\
\text { hoşuma gitti." }\end{array}$ & $\begin{array}{l}\text { "Tek çalıştığımızda } \\
\text { bir tek fikirle } \\
\text { hareket ediyoruz } \\
\text { ama burada grup } \\
\text { arkadaşımla fikir } \\
\text { alışverişi yaptık." }\end{array}$ & $\begin{array}{l}\text { "Matematik hayatın } \\
\text { her yerinde var. } \\
\text { Evimize gelen usta } \\
\text { evimizin ölçüsünü } \\
\text { alıyorlar. Annem } \\
\text { yemek yaparken } \\
\text { matematik } \\
\text { kullanıyor." }\end{array}$ & & $\begin{array}{l}\text { "Diğer } \\
\text { problemlerde her } \\
\text { şeyi hazır veriyor } \\
\text { ama etkinliklerde } \\
\text { bizim bulmamızı } \\
\text { istiyor." (Bilgiye } \\
\text { Ulaşabilme) }\end{array}$ \\
\hline
\end{tabular}


Tablo 2'den hareketle öğrencilerin modelleme etkinlikleri ile ilgili görüşlerinde matematiğe bakış açısı, anlama, eğlenerek öğrenme, grup çalışmaları, etkin katılım ve matematiksel beceriler temaları ortaya çıkmıştır.

Görüşmeler analiz edildiğinde öğrenciler, modelleme etkinlikleri ile işlenen dersler sonucunda matematiğe bakış açılarında değişiklikler olduğunu ifade etmişlerdir. Öğrencilerden biri bu durumu "Matematiği seviyordum ama daha çok sevmeye başladım. Matematiğe daha çok önem vermem gerektiğini fark ettim çünkü matematik hayatın her yerinde varmış” şeklinde ifade etmiştir. $\mathrm{Bu}$ görüşlerden, matematiğin öğrenciler tarafından günlük hayatın kısıtlı bir alanında olduğunu sandıkları ama etkinliklerden sonra bu düşüncelerinin değiştiği sonucuna ulaşılabilir. Ayrıca modelleme etkinliklerinden sonra yüzdeler konusunu daha iyi anladıklarını ifade eden görüşler de vardır. "Etkinlikler sayesinde yüzdeler konusunu daha iyi anladığımı düşünüyorum" ve "Soyut olan matematik bir anda somutlaşmaya başladı" şeklindeki ifadeler öğrencilerin yüzdeler konusunu daha iyi anlamlandırdıklarını göstermektedir.

Modelleme etkinleri kullanılarak yapılan öğretim sırasında genelde öğrenciler için eğlenceli bir ortam oluşmuştur. "Modelleme etkinlikleri eğlenceli ve güzeldi bence" şeklindeki ifadeler öğrencilerin eğlendiklerini ortaya koymaktadır. Bu durum öğrencilerin modelleme etkinlikleri sonucu matematiğe karşı olan tutumlarında olumlu bir değişim olduğunu göstermektedir. Bu çalışmada elde edilen bulgulara göre modelleme etkinliklerinin beğenilen yanlarından biri de etkinliklerin grup çalışması şeklinde yürütülmesidir. Öğrenciler grupla çalışmanın kendileri için güzel bir deneyim olduğunu ifade etmişlerdir. "Grup çalışmasını daha iyi kavramış oldum. Arkadaşımla iletişime geçmeye başladım. Eksikliklerimizi tamamlamadık birbirimizin", "Tek çalıştığımızda tek bir fikirle hareket ediyoruz ama burada grup arkadaşımla fikir alış verişi yaptık" ifadeleri bu duruma örnek olarak gösterilebilir.

Modelleme etkinliklerindeki problemlerin, öğrencilerin karşılaştıkları diğer problemlerden farklı yönlerinden biri günlük hayatla ilişkili olmasıdır. "Modelleme etkinliklerinde daha çok günlük hayatla ilişkili şeyler vardı" şeklindeki öğrenci görüşleri bunu destekler niteliktedir. Bunun dışında öğrencilerin modelleme etkinliklerindeki problemlerin matematiksel beceriler açısından farklılık gösterdiğine ilişkin görüşlerine de rastlanmıştır. "Bu etkinliklerdeki verileri genelde biz oluşturduk ve öyle işlem yaptık. Tek bir cevap yoktu farklı yollar vardı" (Akıl Yürütme). "Tahminlerimiz vardı” (Tahmin Becerileri), "Diğer problemlerde her şeyi hazır veriyor ama etkinliklerde bizim bulmamızı istiyor" (Bilgiye Ulaşabilme) şeklindeki açıklamalar modelleme etkinliklerinin özelliklerinin matematiksel becerilerle ilişkili olabileceği düşüncesinin olduğunu göstermektedir.

\section{TARTIŞMA VE SONUÇ}

$\mathrm{Bu}$ çalışmada, yüzdeler öğretiminde matematiksel modelleme etkinlikleri kullanımına ilişkin öğrenci görüşleri incelenmiştir. Araştırma bulgularına dayanarak şu sonuçlar elde edilmiştir: 
Elde edilen bulgular çerçevesinde matematiksel modelleme etkinlikleriyle yapılan öğretimin öğrencilere kazandırdıklarının başında matematik ve günlük hayat arasındaki ilişkiyi anlamlandırma, eğlenceli ders ortamı, etkin katılım gelmektedir. Bu sonuç birçok araştırmacı tarafından yapılan çalışmalar ile örtüşmektedir (Altun, 2013; Çiltaş ve Işık, 2012; Yıldırım ve Iş̧k, 2015). Ayrıca görüşmelerde grup çalışması da öğrenciler tarafından bir kazanım olarak görülmektedir. Hıdıroğlu, Tekin ve Bukova- Güzel'in (2010), ortaöğretim öğrencisinin bireysel ve birlikte çalışmada matematiksel modellemedeki yaklaşımlarını ve düşünme süreçlerini inceledikleri çalışmalarında da benzer sonuçlar elde etmişlerdir. Öğrencilerle yapılan görüşmelerde öğrencilerin uygulamadan önce de matematiğin günlük hayattaki yerinin farkında olduklarını ancak matematiksel modelleme etkinlikleriyle çalıştıktan sonra bu ilişkinin daha geniş bir alana yayıldığını fark ettikleri belirlenmiş̧tir. Bu durum Doruk’un (2010) çalışmasıyla da örtüşmektedir. Modelleme etkinliklerinin başlarda zorlayıcı olduğunu söyleyen öğrenciler daha sonra kolaylaştığını ve kendilerine daha anlaşılır geldiğini ifade etmişlerdir. Bu ifadelere dayanarak bu çalışmanın sonuçlarının öğrencilerin olumlu matematik deneyimi yaşaması ve bunun öğrencilerin motive olmasını sağlaması noktasında yarar sağladığı ifade edilebilir. Ayrıca matematiğe karşı öğrencilerde bakış açısı değişikliği meydana geldiği, günlük hayatın hemen her alanında matematik olduğunu fark etmelerine katkı sağlamıştır. Bu sonuç Korkmaz'ın (2010) öğretmen adaylarıyla yaptığı çalışmanın sonuçlarıyla örtüşmektedir. Modelleme etkinliklerinin tek bir çözümünün ya da çözüm yolunun bulunmadığ̣ aksine kişiden kişiye değiş̧ebilen, kişinin özgün çözümler üretebildiği etkinlikler olduğu belirlenmiştir. Karabörk (2016) yaptığı çalışmada da benzer bir sonuç elde etmiştir. Bunun dışında öğrencilerin modelleme etkinliklerindeki problemlerin; "Akıl Yürütme", “Tahmin Becerileri” ve "Bilgiye Ulaşabilme” özelliklerinin matematiksel becerilerle ilişkili olabileceği düşüncesinin olduğu ortaya çıkmıştır.

\section{Öneriler}

Yüzdeler öğretiminde matematiksel modelleme etkinlikleri kullanımına ilişkin öğrenci görüşlerini ortaya koymayı amaçlayan bu araştırmanın sonuçlarına dayanarak; literatür tarandığında matematiksel modelleme etkinlikleriyle ilgili ortaokul seviyesinde yeterli çalışma olmadığı görülmektedir. $\mathrm{Bu}$ nedenle matematiksel modelleme etkinlikleri uygulamalarına yönelik daha fazla çalışma yapılması önerilir. Bulgular 1şı̆̆ında ortaokul eğitim programında, öğretmenlerin kolayca erişebileceği, sınıflarda uygulanabilecek modelleme etkinliklerine yer verilmelidir. Araştırma 7. Sınıf öğrencileriyle çalışılmıştır. Farklı sınıf düzeylerinde de bu tarz çalışmalar yapılabilir. Farklı araştırmalarda kontrol grubu da alınarak deneysel bir araştırma ile modelleme etkinliklerin etkisi daha net ortaya konulabilir. Ayrıca öğrencilerin zorlandıkları konulardan biri olan cebirsel ifadeler konusunda da modelleme etkinlikleri tasarlanması ve uygulanması noktasında çalışmalar yapılabilir. 


\section{KAYNAKLAR}

Akgün, L., Çiltaş, A., Deniz, D., Çiftçi, Z. ve Işık, A. (2013). İlköğretim matematik öğretmenlerinin matematiksel modelleme ile ilgili farkındalıkları. Adlyaman Üniversitesi Sosyal Bilimler Enstitüsü Dergisi, 6, 1-34.

Albayrak, E. (2017). Türkiye’ de matematik eğitimi alaninda yayınlanan matematiksel model ve modelleme araştırmalarının betimsel içerik analizi (Yayınlanmamış Yüksek lisans tezi). Atatürk Üniversitesi Eğitim Bilimleri Enstitüsü, Erzurum.

Altun, M. (2013). Ortaokullarda (5, 6, 7 ve 8. sinıflarda) matematik ögrretimi. Bursa: Alfa Aktüel Yayınları.

Balcı, A. (2018). Sosyal bilimlerde araştırma yöntem, teknik ve ilkeler. Ankara: Pegem Akademi Yayınları.

Berry, J. and Houston, K. (1995). Mathematical modelling. Bistrol: J.W. Arrowsmith Ltd.

Beyazit, İ., Aksoy, Y. ve Kırnap, M.S. (2011). Öğretmenlerin matematiksel modelleri anlama ve model oluşturma yeterlilikleri. E-Journal of New World Sciences Academy, 6, 2496-2516.

Blum, W. and LeiB, D. (2007). Deal with modelling problems? Mathematical Modelling. Education, Engineering and Economics-ICTMA 12, 222.

Bukova-Güzel, E. (Ed.). (2016). Matematik eğitiminde matematiksel modelleme. Ankara: Pegem Akademi Yayınları.

Çelik, B. ve Çiltaş, A. (2015). Beşinci sınıf kesirler konusunun öğretim sürecinin matematiksel modeller açısından incelenmesi. Bayburt Üniversitesi Eğitim Fakültesi Dergisi, 10, 179-204.

Çiltaş, A. (2011). Eğitimde öz düzenleme öğretiminin önemi üzerine bir çalışma. Mehmet Akif Ersoy Üniversitesi Sosyal Bilimler Enstitüsü Dergisi, 3(5), 1-11.

Çiltaş, A. ve Işık, A. (2012). İlköğretim matematik öğretmeni adaylarının dizi ve serilerle ilgili zihinsel modellerinin belirlenmesi. Erzincan Üniversitesi Ĕ̈itim Fakültesi Dergisi, 14(2), 167-182.

Çiltaş, A. (2017). Türkiye'de matematik eğitimi alanında yayınlanan matematiksel model ve modelleme araştırmalarının betimsel içerik analizi. Uluslararası Türk Eğitim Bilimleri Dergisi, 5(9), 258-283.

Doruk, B. K. (2010). Matematiği günlük yaşama transfer etmede matematiksel modellemenin etkisi (Yayınlanmamış Doktora tezi). Hacettepe Üniversitesi Sosyal Bilimler Enstitüsü, Ankara.

Ekiz, D. (2009). Bilimsel Araşstırma Yöntemleri. Ankara: Anı Yayıncılık.

Erbaş, A.K., Kertil, M., Çetinkaya, B. ve Çakıroğlu, E. (2014). Matematik eğitiminde matematiksel modelleme: Temel kavramlar ve farklı yaklaşımlar. Kuram ve Uygulamada Eğitim Bilimleri, 14(4), $1-21$.

Erol, M. (2015). Modelleme etkinliklerinin 9. sını öğrencilerinin matematiksel okuryazarlıkları ve inançları üzerine etkisi. (Yayınlanmamış doktora tezi). Balıkesir Üniversitesi Fen Bilimleri Enstitüsü, Balıkesir.

Gümüş, İ., Demir, Y., Koçak, E., Kaya, Y. ve Kırıcı, M. (2008). Modelle öğretimin öğrenci başarısına etkisi. Erzincan Eğitim Fakültesi Dergisi, 10(1), 65-90.

Hıdıroğlu, Ç. N., Tekin, A. ve Bukova-Güzel, E. (2010, Eylül). Öğrencilerin matematiksel modellemede bireysel ve birlikte çalışarak ortaya koydukları yaklaşımlar ve düşünme süreçleri, 9. Ulusal Fen Bilimleri ve Matematik Ĕgitimi Kongresi, İzmir. 
Hıdıroğlu, Ç. N. (2012). Teknoloji destekli ortamda matematiksel modelleme problemlerinin çözüm süreçlerinin analiz edilmesi: Yaklaşım ve düşünme süreçleri üzerine bir açıklama (Yayınlanmamış Doktora tezi). Dokuz Eylül Üniversitesi Eğitim Bilimleri Enstitüsü, İzmir.

Hıdıroğlu, Ç. N. ve Özkan-Hıdıroğlu, Y. (2017). Altıncı sınıf öğrencilerinin matematiksel modellemede oluşturdukları gerçek yaşam problem durumu modelleri. İlköğretim Online, 16(4), 1702-1731.

Kal, F. M. (2013). Matematiksel modelleme etkinliklerinin ilköğretim 6. sinıf öğrencilerinin problemi çözme tutumlarına etkisi (Yayınlanmamış yüksek lisans tezi). Kocaeli Üniversitesi Fen Bilimleri Enstitüsü, Kocaeli.

Karabörk, M. A. (2016). Model oluşturma etkinliklerinin 7. Sinıf öğrencilerinin matematik dersi başarılarına etkisi ve ögrencilerin etkinliklere yönelik görüşleri (Yayınlanmamış yüksek lisans tezi). Abant İzzet Baysal Üniversitesi Eğitim Bilimleri Enstitüsü, Bolu.

Kertil, M. (2008). Matematik öğretmen adaylarının problem çözme becerilerinin modelleme sürecinde incelenmesi (Yayınlanmamış yüksek lisans tezi). Marmara Üniversitesi Eğitim Bilimleri Enstitüsü, İstanbul.

Keskin, Ö. Ö. (2008). Ortaöğretim matematik öğretmen adaylarının matematiksel modelleme yapabilme becerilerinin geliştirilmesi üzerine bir araştırma (Yayınlanmamış doktora tezi). Gazi Üniversitesi Eğitim Bilimleri Enstitüsü, Ankara.

Kilpatrick, J. (1992). A history of research in mathematics education. Handbook of research on mathematics teaching and learning (pp. 3-38). D. Grouws. New York, Macmillan.

Koay, P. L. (1998). The knowledge of percent of pre-service teachers. The Mathematics Educator,3(2), 5469.

Korkmaz, E. (2010). İlköğretim matematik ve sınıf öğretmeni adaylarının matematiksel modellemeye yönelik görüşleri ve matematiksel modelleme yeterlikleri (Yayınlanmamış doktora tezi). Balıkesir Üniversitesi Fen Bilimleri Enstitüsü, Balıkesir.

Lembke, L. O. and Reys, B. J. (1994). The development of, and interaction between, intuitive and schooltaught ideas about percent. Journal for Research in Mathematics Education, 25(3), 237-259.

Lesh, R. E. and Doerr, H. M. (2003). Beyond constructivism: Models and modeling perspectives on mathematics problem solving, learning, and teaching. Lawrence Erlbaum Associates Publishers.

Milli Eğitim Bakanlığı [MEB], (2013). Ortaokul matematik dersi (5, 6, 7 ve 8. sinıflar) öğretim programı. Ankara: Milli Eğitim Basımevi.

Milli Eğitim Bakanlığı [MEB], (2015). Ortaokul matematik dersi (5, 6, 7 ve 8. sinıflar) öğretim programı. Ankara: Milli Eğitim Basımevi.

Mumcu, H. Y. ve Baki, A. (2017). Matematiği kullanma aktivitelerinde matematiksel modellemenin yorumlanması. Ondokuz Mayls Üniversitesi Eğitim Fakültesi Dergisi, 36(1), 7-33.

Muşlu, M. ve Çiltaş, A. (2016). Doğal sayılarda işlemler konusunun öğretiminde matematiksel modelleme yönteminin öğrenci başarısına etkisi. Bayburt Eğitim Fakültesi Dergisi, 11(2), 329-343.

Parker, M. and Leinhardt, G. (1995). Percent: A privileged proportion. Review of Educational Research, 65(4), 421-481. 
Sandalcı, Y. (2013). Matematiksel modelleme ile cebir öğretiminin öğrencilerin akademik başarılarına ve matematiği günlük yaşamla ilişkilendirmelerine etkisi (Yayınlanmamış Yüksek Lisans Tezi). Recep Tayyip Erdoğan Üniversitesi Sosyal Bilimler Enstitüsü, Rize.

Swetz, F. and Hartzler J. S. (1991). Mathematical modeling in the secondary school curriculum. NCTM: Reston, Virginia.

Van De Walle, J. A., Karp, K. S. and Bay-Williams, J. M. (2012). İlkokul ve ortaokul matematiği: Gelişimsel yaklaşımla öğretim. S. Durmuş (Ed.). (7. baskı) Ankara: Nobel Yayıncılık.

Yıldırım, Z. ve Işık, A. (2015). Matematiksel modelleme etkinliklerinin 5.sınıf öğrencilerinin matematik dersindeki akademik başarılarına etkisi. Kastamonu Ĕ̌itim Dergisi, 23(2), 581-600.

Yıldırım, A. ve Şimşek, H. (2016). Sosyal bilimlerde nitel araştırma yöntemleri. Ankara: Seçkin Yayıncılık. 